\title{
Septic shock: ECMO beyond ARDS? Introducing the Simon two-stage protocol when randomisation is considered unethical
}

\author{
Alexander Buia ${ }^{1 *} \mathbb{D}$, Hans-Bernd Hopf ${ }^{2}$, Eva Herrmann ${ }^{3}$, Thomas Schmandra ${ }^{4}$ and Ernst Hanisch ${ }^{1}$
}

One of the great disappointments during the past decades has been the failure to convert advances in our understanding of the biologic features of sepsis into new therapies. Although numerous multicenter, randomized controlled trials have been conducted in the last 30 years, no reduction of septic shock mortality was achieved [1] [2]. [3] Taking together available evidence suggests that no sepsis specific therapies are available until today, although a roadmap on the way to a specific septic shock therapy might be on the horizon [3] [4] including artificial intelligence [5]. [6].

Interestingly, in the Surviving Sepsis Campaign guidelines [7] ECMO (Extra Corporal Membrane Oxygenation) is not mentioned as a treatment option.

ECMO has been a standard treatment for cardiac and respiraory failure in neonates and children for decades, [8] in contrast to adults where the debate about the benefit of ECMO still is ongoing.

A systematic review and meta-analysis showed that the use of veno-arterial life support (ECLS) in cardiac arrest was associated with a higher survival (NNT [number needed to treat] 7.7) as well as a better neurological outcome, in the setting of cardiogenic shock there was a higher survival with ECLS compared with IABP (NNT 3) [9].

Since even the efficacy of venovenous extracorporal membrane oxygenation with severe respiratory distress syndrome (ARDS) has been disputed controversially

\footnotetext{
* Correspondence: a.buia@asklepios.com

'Department of General, Visceral and Thoracic Surgery, Asklepios Klinik

Langen, Academic Teaching Hospital Goethe-University Frankfurt, Röntgenstr 20, 63225 Langen, Germany

Full list of author information is available at the end of the article
}

until today a randomized controlled trial comparing vvECMO with conventional treatment was initiated with the results published recently (EOLIA trial) [10]. The main causes of ARDS were bacterial pneumonia in $45 \%$ and viral pneumonia in $18 \%$ of the patients, $78 \%$ of the patients had severe sepsis or septic shock. Primary end point was mortality at 60 days. No difference was found in the initial intention-to-treat analysis. However, 35 patients $(28 \%)$ in the control group crossed over to ECMO. In fact, reanalysis including crossover patients as treatment failure and comparing death/crossover to ECMO of the control group vs death in the ECMO group showed a $23 \%$ lower mortality in the ECMO group (NNT 5).

In addition, Robert Bartlett in an editorial in CCM argued that the difference of the intention to treat vs treatment failure analysis results from 35 patients in the conventional care group who crossed over to the ECMO group as rescue treatment when conventional care was failing. Accordingly, the study had become a study of early versus late ECMO. Therefore, the EOLIA trial had shown that ECMO should be used promptly when highrisk criteria are met, rather than as late rescue therapy when death from ARDS or multiple organ failure is imminent [11].

What about the use of va-ECMO in the treatment of septic shock? To date, ECMO is suggested only as rescue therapy [12] and only observational case series with some promising results have been published (for overview see Table 1). However, the impression is not unequivocal. Thus, in a commentary discussing the results of Ro et al. the question is asked whether ECMO therapy in septic shock is a heroic futility or not [27]. The 
Table 1 Observational studies using ECMO in adult septic shock, modified and extended according to Riera [13] et al.

\begin{tabular}{|c|c|c|c|c|}
\hline Study & N & $\begin{array}{l}\text { Sites of infection } \\
\%\end{array}$ & $\begin{array}{l}\text { ECMO } \\
\text { configuration }\end{array}$ & $\begin{array}{l}\text { Hospital } \\
\text { Survival } \\
\%\end{array}$ \\
\hline Brechot et al. [14] & 14 & $\begin{array}{l}\text { Pneumonia bacterial } 79 \\
\text { Abdomen } 14,3\end{array}$ & $\begin{array}{l}\text { Peripheral va } 36 \% \\
\text { Switch to vv }\end{array}$ & 71 \\
\hline Huang et al. [15] & 52 & $\begin{array}{l}\text { Pneumonia } 48 \\
\text { Abdomen } 23 \\
\text { Urinary tract 9,6 }\end{array}$ & Peripheral va & 15 \\
\hline Cheng et al. [16] & 108 & $\begin{array}{l}\text { Pneumonia bacterial } 40 \\
\text { Myocarditis } 25 \\
\text { Primary bloodstream 19,4 }\end{array}$ & $\begin{array}{l}\text { Peripheral va } 78,7 \\
\text { Peripheral vv } 21,3\end{array}$ & 28,7 \\
\hline Park et al. [17] & 32 & $\begin{array}{l}\text { Pneumonia bacterial } 34,4 \\
\text { Abdomen } 21,9 \\
\text { Urinary tract } 12,5\end{array}$ & Peripheral va & 21,9 \\
\hline Cheng et al. [18] & 151 & $\begin{array}{l}\text { Pneumonia } 50,3 \\
\text { Myocarditis } 19,9 \\
\text { Bloodstream } 14,6 \\
\text { Abdomen } 7,6\end{array}$ & $\begin{array}{l}\text { Peripheral va } 66,9 \\
\text { vv } 33,1\end{array}$ & 29,8 \\
\hline Von Bahr et al. [19] & 255 & $\begin{array}{l}\text { Pneumonia bacterial } 53 \\
\text { Pneumonia viral } 12,5\end{array}$ & $\begin{array}{l}\text { vv } 68 \\
\text { switch to va } \\
\text { peripheral } 21 \\
\text { switch to vv } 16\end{array}$ & 64 \\
\hline Takauji et al. [20] & 40 & $\begin{array}{l}\text { Pneumonia } 62,5 \\
\text { Abdomen } 20 \\
\text { Urinary tract } 7,5\end{array}$ & vV & 47,5 \\
\hline Yeo et al. [21] & 8 & $\begin{array}{l}\text { Pneumonia } n=5 \\
\text { Extra-pulmonary } n=3\end{array}$ & vva & 50 \\
\hline Choi et al. [22] & 28 & $\begin{array}{l}\text { Pulmonary } 46,4 \\
\text { Abdomen } 14,3 \\
\text { Genitourinary } 7,1 \\
\text { Skin or soft tissue 14,3 } \\
\text { Cardiovascular } 7,1 \\
\text { Central nerve system 3,6 } \\
\text { Catheter-induced 3,6 } \\
\text { Other 3,6 }\end{array}$ & vv, va, vva & 35,7 \\
\hline Ro et al. [23] & 71 & $\begin{array}{l}\text { Pneumonia } 70 \\
\text { Abdomen } 11 \\
\text { Urinary tract } 5 \\
\text { Other } 14\end{array}$ & va & 7 \\
\hline Vogel et al. [24] & 12 & Septic cardiomyopathy $n=12$ & vva & 75 \\
\hline Banjas et al. [25] & 19 & $\begin{array}{l}\text { Pneumonia } 53 \\
\text { Abdomen } 42 \\
\text { Soft tissue } 5\end{array}$ & vv, va, vva & 42 \\
\hline Falk et al. [26] & 37 & $\begin{array}{l}\text { Lung } n=21 \\
\text { Gut } n=2 \\
\text { Pyelonephritis } n=4 \\
\text { Fasciitis } n=4 \\
\text { Urine } n=1 \\
\text { Blood } n=4 \\
\text { Myocarditis } n=1\end{array}$ & vV, va & $\begin{array}{l}\text { Distributive } \\
\text { shock } 70,6 \\
\text { Cytotoxic } \\
\text { Cardiac failure } \\
90,0\end{array}$ \\
\hline
\end{tabular}

authors come to the conclusion that in this study more than half of the patients had liver cirrhosis, including post-liver transplantation and the patient cohort was derived from the years 2005 through 2012; both factors could adversely affect outcomes. On the contrary, the results of a just recently published observational study [26] are very promising with a hospitality mortality of just
$10 \%$ in cytotoxic cardiac failure and $30 \%$ in distributive shock.

In this situation where randomized controlled trials are considered unethical, Bartlett suggests that the matched pairs method is the best study design for evaluation of life support systems in acute fatal illness in a high risk population early [8]. 
For patients with septic shock we suggest another approach - the Simon [28] two-stage non-randomized method including only patients with septic shock (Sepsis-3 definition [7];) resulting from secondary peritonitis.

The Simon protocol is a Phase 2 design. According to Evrard et al. "Phase 2 is a completely underutilized tool in surgery that could raise the level of scientific reporting. The threshold for efficacy and nonefficacy is defined and with statistical power (risks $a$ and $b$ ), the cohort size is calculated (usually, between 30 and 60 patients). The use of interim stopping rules allows reduction of the required number of patients (e.g., Simon design)" [29].

We use the following assumptions: ECMO treatment is considered as poor $\left(\mathrm{P}_{0}\right)$ if mortality is above $55 \%$ and as sufficient $\left(\mathrm{P}_{1}\right)$ if it is below $40 \%$ with a two-sided alpha of 0.05 and a beta of 0.20 .

Inclusion criteria: Overcoming the criticism of sepsis trials in the past, namely heterogeneity of patient populations (ie mixing medical and surgical patients), we are only studying septic shock due to secondary peritonitis, a group with a reported very high mortality; age: $18-70$ years, norepinephrine $>0,5 \mu \mathrm{g} / \mathrm{kg} / \mathrm{min}$ despite adequate volume substitution $(30 \mathrm{ml} / \mathrm{kg})$ within the first $12 \mathrm{~h}$, serum lactate $>2 \mathrm{mmol} / \mathrm{l}$, duration of septic shock $<24 \mathrm{~h}$ (ie ECMO is initiated as an early and not as a rescue therapy); Exclusion criteria: Septic shock due to other sources than the abdomen, peripheral arterial occlusive disease excluding femoral/axillary vessel cannulation; duration of septic shock $>24 \mathrm{~h}$; patient waiver concerning life support measures.

The ECMO route is peripheral with an initial flow $\geq 4.5 \mathrm{l} / \mathrm{min}$ and norepinephrine should be reduced at least to below norepinephrine $>0,5 \mu \mathrm{g} / \mathrm{kg} / \mathrm{min}$. The standard protocol in patients with VA-ECMO is to adjust the blood flow of the machine and the dosage of norepinephrine in order to achieve a mean arterial pressure of at least $65 \mathrm{mmHg}$. After achieving this MAP norepinephrine is tapered if possible, to below $0.1 \mu \mathrm{g} / \mathrm{kg} /$ min. In addition, inferior vena cava saturation is monitored continuously with a target saturation above 55 . Finally, transthoracic echocardiography is performed daily when norepinephrine dosage is above $0.5 \mu \mathrm{g} / \mathrm{kg} / \mathrm{min}$.

CRRT will be used while on ECMO (default CRRT is SLED, it might be possible to use the oxygenator for connecting the dialysis machine, depending on the arterial and internal pressure of the oxygenator, if too high, a separate dialysis catheter has to be established). Distal arterial limb perfusion is used in every patient by a $6 \mathrm{~F}$ sheat strengthened by wire. Filters for removing cytokines are not allowed.

The design with a moderate cluster effect results in the following study conditions: Include 40 patients at a first stage and reject the approach if 16 or less patients survive (and 24 more die).
Otherwise, the second stage will be recruited until overall $n=79$ patients are included. The treatment approach will be rejected if overall 43 or less patients survive (i. e., 36 or more patients die).

This study design follows important recommendations: First, it is not a randomized trial (ie avoiding ethical issues, [30] [8]; and second, the defined patient population has a high mortality risk and avoids heterogeneity. Moreover, the Simon approach leads rapidly to results in a small number of patients in which a minimum of data collection could be provided [31].

In conclusion in answering the question 'Septic shock ECMO beyond ARDS?' we strongly believe, against the background of quite discrepant results of observational studies (see Table 1 [13])that va-ECMO should be studied as outlined in the above protocol with emphasis on early ECMO (ie not as rescue ECMO) when failure of conventional therapy for septic shock is evident: norepinephrine $>0,5 \mu \mathrm{g} / \mathrm{kg} / \mathrm{min}$ despite adequate volume substitution (30 $\mathrm{ml} / \mathrm{kg}$ ) within the first $12 \mathrm{~h}$ and serum lactate $>2 \mathrm{mmol} / \mathrm{l}$.

\section{Abbreviations \\ ECMO: extra corporal membrane oxygenation; ARDS: Acute respiratory distress syndrome; va: veno-arterial; vV: venovenous; NNT: number needed to treat; RRT: renal replacement therapy; SLED: sustained low efficiency dialysis}

\section{Acknowledgements \\ Not applicable}

\section{Authors' contributions}

A. Buia did the literature research, wrote and revised the manuscript, $H$.B. Hopf wrote and revised the manuscript, E. Herrmann did the statistical advice, wrote and revised the manuscript, T. Schmandra did the literature research, wrote and revised the manuscript, E. Hanisch did the literature research, contribute the table, wrote and revised the manuscript. The authors read and approved the final manuscript.

\section{Funding}

None

Availability of data and materials Not applicable

Ethics approval and consent to participate Not applicable

Consent for publication

Not applicable

\section{Competing interests}

All authors declare that they have no competing interests.

\section{Author details}

${ }^{1}$ Department of General, Visceral and Thoracic Surgery, Asklepios Klinik Langen, Academic Teaching Hospital Goethe-University Frankfurt, Röntgenstr 20, 63225 Langen, Germany. 'Department of Anaesthesia and Perioperative Medicine, Asklepios Klinik Langen, Academic Teaching Hospital

Goethe-University Frankfurt, Röntgenstr 20, 63225 Langen, Germany.

${ }^{3}$ Department of Biostatistics and Mathematical Modeling, Goethe-University Frankfurt, Theodor-Stern-Kai 7, 60590 Frankfurt, Germany. ${ }^{4}$ Department of Vascular Surgery, Rhön Klinik Campus Bad Neustadt, Von-Guttenberg-Str. 11, 97616 Bad Neustadt a. d. Saale, Germany. 
Received: 9 August 2019 Accepted: 2 March 2020

Published online: 17 March 2020

\section{References}

1. Angus DC. The search for effective therapy for sepsis. JAMA. 2011;306:2614

2. de Grooth HJ, Postema J, Loer SA, Parienti JJ, Oudemans-van Straaten HM, Girbes AR. Unexplained mortality differences between septic shock trials: a systematic analysis of population characteristics and control-group mortality rates. Intensive Care Med. 2018:44:311-22.

3. Singer M, Deutschman CS, Seymour CW, Shankar-Hari M, Annane D, Bauer $M$, et al. The third international consensus definitions for Sepsis and septic shock (Sepsis-3). JAMA. 2016;315:801-10.

4. Opal SM, Dellinger RP, Vincent JL, Masur H, Angus DC. The next generation of sepsis clinical trial designs: what is next after the demise of recombinant human activated protein C? Crit Care Med. 2014:42:1714-21.

5. Komorowski M, Celi LA, Badawi O, Gordon AC, Faisal AA. The artificial intelligence clinician learns optimal treatment strategies for sepsis in intensive care. Nat Med. 2018;24:1716-20.

6. Hanisch E, Brause R, Paetz J, Arlt B. Review of a large clinical series: predicting death for patients with abdominal septic shock. J Intensive Care Med. 2011;26:27-33.

7. Rhodes A, Evans LE, Alhazzani W, Levy MM, Antonelli M, Ferrer R, et al. Surviving Sepsis campaign: international guidelines for Management of Sepsis and Septic Shock: 2016. Intensive Care Med. 2017;43:304-77.

8. Bartlett RH. Clinical research in acute fatal illness: lessons from extracorporeal membrane oxygenation. J Intensive Care Med. 2016;31:45665.

9. Ouweneel DM, Schotborgh JV, Limpens J, Sjauw KD, Engström AE, Lagrand WK, et al. Extracorporeal life support during cardiac arrest and cardiogenic shock: a systematic review and meta-analysis. Intensive Care Med. 2016;42: 1922-34.

10. Combes A, Hajage D, Capellier G, Demoule A, Lavoué S, Guervilly C, et al. Extracorporeal membrane oxygenation for severe acute respiratory distress syndrome. N Engl J Med. 2018;378:1965-75.

11. Bartlett R. Extracorporal membrane oxygenation for acute respiratory distress syndrome: EOLIA and beyond. Crit Care Med. 2019;47:114-7.

12. Moore S, Weiss B, Pascual JL, Kaplan LJ. Management of acute respiratory failure in the patient with sepsis or septic shock. Surg Infect. 2018;19:191201.

13. Riera J, Argudo E, Ruiz-Rodríguez JC, Ferrer R. Extracorporeal membrane oxygenation for adults with refractory septic shock. ASAIO J. 2018. https:// doi.org/10.1097/MAT.0000000000000905.

14. Bréchot $N$, Luyt C-E, Schmidt $M$, Leprince $P$, Trouillet J-L, Léger $P$, et al. Venoarterial extracorporeal membrane oxygenation support for refractory cardiovascular dysfunction during severe bacterial septic shock. Crit Care Med. 2013;41:1616-26. 20.

15. Huang C-T, Tsai Y-J, Tsai P-R, Ko W-J. Extracorporeal membrane oxygenation resuscitation in adult patients with refractory septic shock. J Thorac Cardiovasc Surg. 2013;146:1041-6.21.

16. Cheng A, Sun H-Y, Lee C-W, Ko W-J, Tsai P-R, Chuang Y-C, et al. Survival of septic adults compared with nonseptic adults receiving extracorporeal membrane oxygenation for cardiopulmonary failure: A propensity-matched analysis. J Crit Care. 2013;28:532.e1-10. 22

17. Park TK, Yang JH, Jeon K, Choi S-H, Choi J-H, Gwon H-C, et al. Extracorporeal membrane oxygenation for refractory septic shock in adults. Eur J Cardio Thoracic Surg. 2015;47:e68-74.23.

18. Cheng A, Sun H-Y, Tsai M-S, Ko W-J, Tsai P-R, Hu F-C, et al. Predictors of survival in adults undergoing extracorporeal membrane oxygenation with severe infections. J Thorac Cardiovasc Surg. 2016;152:1526-1536.e1.

19. von Bahr V, Hultman J, Eksborg S, Frenckner B, Kalzén H. Long-term survival in adults treated with extracorporeal membrane oxygenation for respiratory failure and Sepsis. Crit Care Med. 2017:45:164-70.

20. Takauji S, Hayakawa M, Ono K, Makise H. Respiratory extracorporeal membrane oxygenation for severe sepsis and septic shock in adults: a propensity score analysis in a multicenter retrospective observational study. Acute Med Surg. 2017:4:408-17.

21. Yeo HJ, Jeon D, Kim YS, Cho WH, Kim D. Veno-veno-arterial extracorporeal membrane oxygenation treatment in patients with severe acute respiratory distress syndrome and septic shock. Crit Care. 2015;20:28.

22. Choi MJ, Ha SO, Kim HS, Park S, Han SJ, Lee SH. The simplified acute physiology score II as a predictor of mortality in patients who underwent extracorporeal membrane oxygenation for septic shock. Ann Thorac Surg. 2017;103:1246-53.

23. Ro SK, Kim WK, Lim JY, Yoo JS, Hong S-B, Kim JB. Extracorporeal life support for adults with refractory septic shock. J Thorac Cardiovasc Surg. 2018;156: 1104-1109.e1.

24. Vogel DJ, Murray J, Czapran AZ, Camporota L, loannou N, Meadows CIS, et al. Veno-arterio-venous ECMO for septic cardiomyopathy: a single-centre experience. Perfusion. 2018;33(1_suppl):57-64.

25. Banjas N, Hopf H-B, Hanisch E, Friedrichson B, Fichte J, Buia A. ECMOtreatment in patients with acute lung failure, cardiogenic, and septic shock: mortality and ECMO-learning curve over a 6-year period. J Intensive Care. 2018;6:84. https://doi.org/10.1186/s40560-018-0352-2.

26. Falk L, Hultman J, Broman LM. Extracorporeal membrane oxygenation for septic hock. Crit Care Med. 2019;47:1097-105.

27. Pagani FD. Extracorporeal membrane oxygenation for septic shock: heroic futility? J Thorac Cardiovasc Surg. 2018;156:1110-1.

28. Simon R. Optimal two-stage designs for phase II clinical trials. Control Clin Trials. 1989;10:1-10.

29. Evrard S, Audisio R, Poston G, Caballero C, Kataoka K, Fontein D, et al. From a comic opera to Surcare an open letter to whom clinical research in surgery is a concern. Ann Surg. 2016;264:911-2.

30. Gattinoni L, Vasques F, Quintel M. Use of ECMO in ARDS: does the EOLIA trial really help? Crit Care. 2018;22:171

31. Vincent J-L, Martin-Loeches I, Annane D. What patient data should be collected in this randomized controlled trial in sepsis? Intensive Care Med 2016:42:2011-3.

\section{Publisher's Note}

Springer Nature remains neutral with regard to jurisdictional claims in published maps and institutional affiliations.

Ready to submit your research? Choose BMC and benefit from:

- fast, convenient online submission

- thorough peer review by experienced researchers in your field

- rapid publication on acceptance

- support for research data, including large and complex data types

- gold Open Access which fosters wider collaboration and increased citations

- maximum visibility for your research: over $100 \mathrm{M}$ website views per year

At $\mathrm{BMC}$, research is always in progress.

Learn more biomedcentral.com/submissions 